K L-аргинина и урсодезоксихолевой кислоты в терапии розацеа

\author{
М.К. Балтабаев ${ }^{1}$, А.Т. Шакирова², А.М. Балтабаев ${ }^{1}$
}

${ }^{1}$ ГБОУ высшего профрессионального образования Кыргызско-Российский Славянский университет им. первого президента России Б.Н. Ельцина

720000 , г. Бишкек, ул. Киевская, д. 44

${ }^{2}$ Кыргызская государственная медицинская академия им. И.К. Ахунбаева

720020, г. Бишкек, ул. Ахунбаева, д. 92

Проведено клиническое наблюдение 77 больных различными клиническими формами розацеа, получавшими патогенетический метод лечения L-аргинином и препаратами урсодезоксихолевой кислоты. У большинства больных до начала лечения выявлена функциональная и органическая патология гепатобилиарной системы, которая подтверждена лабораторными методами исследований. Включение L-аргинина и урсодезоксихолевой кислоты в комплексную терапию розацеа способствовало как нормализации печеночных тестов, так и регрессу кожных высыпаний.

Ключевые слова: розацеа, урсодезоксихолевая кислота, L-аргинин, печеночные тесты.

Контактная информация: mir-ali@yandex.ru. Вестник дерматологии и венерологии 2016; (6): 34-42.

\title{
C \\ linical efficasy of L-arginine and ursodeoxycholic acid in the complex treatment of rosacea
}

\section{M.K. Baltabaev¹, A.T. Shakirova², A.M. Baltabaev ${ }^{1}$}

${ }^{1}$ State State-Funded Educational Institution Kyrgyz-Slavonic University named after the first president of Russia B.N. Yeltsin

Kievskaya str., 44, Bishkek, 720000, Kyrgyz Republic

${ }^{2}$ I.K. Akhunbaev Kyrgyz State Medical Academy

Akhunbaev str., 92, Bishkek, 720020, Kyrgyz Republic

\section{Under clinical observation were 77 patients suffered from different clinical forms of acne rosacea that using L-arginin and Ursodeoxycholic acid had treated All patients have functional and organic disturbances of hepatobiliary system before treatment. Complex treatment including L-arginin and Ursodeoxycholic acid led to improvement of balance of liver enzymes and lipid fractions in peripheric blood of investigated patients.}

Key words: rosacea, Ursodeoxycholic acid, L-arginine, Liver enzymes. 
Терапия розацеа является одним из актуальных вопросов практической дерматологии из-за большой распространенности этого дерматоза среди населения. Заболеваемость данной кожной патологией составляет 2-5\% и может достигать 10\%, а в некоторых странах, как в Эстонии, 22\% [1-4]. Заболевание часто встречается у лиц наиболее трудоспособного возраста (30-40 лет) и достигает своего пика в 50-60 лет, угнетая психику больных. Согласно рекомендации национального экспертного комитета по проблеме розацеа выделяют четыре клинические формы: эритематозно-телеангиэктатическая, папуло-пустулезная, фриматозная и офтальморозацеа [5]. В некоторых ретроспективных исследованиях отмечено, что частота клинических фрорм розацеа вариабельна, так, эритематозно-телеангиэктатическая форма составляет $12 \%$, папуло-пустулезная - 69\%, риносрима - 3,7\% среди поликлинических больных [6].

Имеются работы как отечественных, так и зарубежных ученых, посвященные изучению патогенеза розацеа. В очагах поражений наблюдается активация Toll-подобных рецепторов кератиноцитов (TLRs) с последующим высвобождением антимикробных пептидов (AMP), в частности кателицидина LL-37 и сериновой протеазы - калликреина 5 [7, 8]. Колонизация очагов розацеа, в частности пилосебационного комплекса фолликулов, Demodex folliculorum и другими микроорганизмами - Staphylococcus epidermidis, Bacillus oleronius и в желудочно-кишечном тракте Helicobacter pylori, способствует активации Toll-like peцепторов-2 кератиноцитов, имеющих значение в патогенезе дерматоза [9-11]. Отмечено повышение экспрессии клетками моноцитарной системы фрактора некроза опухолей (TGF $\beta 1$ и TGF $\beta 2$ ) в очагах поражений у больных, страдающих фиматозной формой розацеа [12]. У больных розацеа, страдающих блефаритом, обусловленным Demodex folliculorum, наблюдалось повышение уровня содержания IL-7, IL-12 и IL-17 в слезной жидкости по сравнению с больными розацеа при отсутствии клещей [12]. Кроме того, возникновение в очагах розацеа эритемы и нейросенсорных симптомов, таких как боль, жжение, покалывание, может быть обусловлено выделением дополнительно вазоактивных пептидов, таких как TRPV1, которые высвобождаются при раздражении кожных нервных окончаний [13-15]. В связи с этим многие авторы относят розацеа к хроническим ангионеврозам кожи лица [15].

Большое значение придается нарушениям функционального состояния желудочно-кишечного тракта [16-19, 21, 25]. Ряд авторов выявили при розацеа клинические и гистологические признаки гастрита [22], патологию слизистой оболочки тощей кишки [20], имеются сообщения о наличии у больных розацеа язвенного колита [23]. Обсуждается роль Helycobacter pylori, этиологического фактора хронического активного гастрита типа В в патогенезе роза- цеа [24, 26, 27]. Выявлена корреляция между розацеа и патологией гепатобилиарной системы [17-19, 22]. У больных данным дерматозом выявлены нарушения липидного обмена, изменения качественного состава плазмы, нарушения в системе перекисного окисления и антиоксидантной системы [19]. Накопление промежуточных метаболитов служит показателем степени эндогенной интоксикации организма больных [25]. Следует отметить тот факт, что ряд авторов не поддерживают то положение, что розацеа коррелирует с патологией желудочно-кишечного тракта, так как не наблюдались достоверные различия в частоте указанных явлений в контрольной группе, но без кожных проявлений [26, 27].

Терапия розацеа в настоящее время основывается на выявленных отдельных изменениях в патогенезе болезни, которые в большинстве случаев носят фрагментарный характер. Несмотря на это, применение антибиотиков, чаще тетрациклинового ряда, производных метронидазола, и при тяжелых фрормах течения кожного процесса ретиноидов, включено в международные клинические протоколы как общепринятый стандарт терапии розацеа [28]. До сих пор отсутствует единое мнение по механизму терапевтического действия вышеуказанных препаратов.

В настоящее время большое внимание в медицинской практике уделяется аминокислотам, обладающим лечебным действием. Одной из важнейших является аргинин - предшественник орнитина, цитрулина, глутамина, глутатиона, гамма-аминомасляной кислоты и других соединений. Он является условно незаменимой аминокислотой, его недостаток ведет к быстрому развитию патологических процессов [29, 30].

В биосистемах аргинин играет важную роль в синтезе ряда анаболических гормонов, полиаминов и оксида азота [31-33].

Дефицит аргинина в питании замедляет рост организма [29]. Аргинин укрепляет иммунную систему, увеличивая активность Т-клеточного иммунитета (усиливает продукцию интерлейкина-2, лимфоцитов и их рецепторную активность), устраняя иммунодесицитные состояния [32]. Аргинин усиливает пролиферацию Т-лимфоцитов [32, 34]. Он повышает концентрацию инсулина и инсулиноподобного фрактора роста в плазме крови, улучшает азотистый баланс у раковых больных [34].

Анализ литературных данных и собственных клинических исследований свидетельствует о наличии у больных розацеа частой функциональной и органической патологии гепатобилиарной системы, что послужило основанием для дополнительного использования нами в комплексной терапии производных урсодезоксихолевой кислоты (УДХК) с целью коррекции вышеуказанных изменений [35-37].

Препараты УДХК улучшают экскреторную функцию печени путем воздействия на процессы эмульги- 
рования жиров, усиливают перистальтику кишечника, а также обладают иммунокорригирующими свойствами [35]. Положительный эфффект данный препарат дает при лечении хронических гепатитов и гепатозов печени [35].

Цель исследования - провести оценку эффрективности препаратов - урсодезоксихолевой кислоты и L-аргинина в комплексной терапии различных клинических фрорм розацеа [39].

\section{Материал и методы}

До начала патогенетического лечения L-аргинином и урсодезоксихолевой кислотой в комплексной терапии пациенты заполняли фрорму информированного согласия на добровольное участие в исследовании с уведомлением о препаратах, длительности курса лечения и возможных побочных явлениях проводимой терапии.

Дизайн исследования - открытое сравнительное исследование продолжительностью 70 недель, в котором приняли участие 77 больных различными формами розацеа. Все пациенты разделены на две группы 53 и 24 человека, соответствующие друг другу по показателям степени тяжести заболевания, полу и возрасту. Пациенты в первой группе (основная группа) получали комплексное лечение с применением L-аргинина и урсодезоксихолевой кислоты [39], при папуло-пустулезной (35 больных) и фриматозной (4 больных) формах дополнительно применялся препарат тетрациклинового ряда (доксициклин) с индивидуальной курсовой дозой до разрешения гнойных элементов. В тяжелых случаях при отсутствии клинического эффекта от антибактериальной терапии и при выделении резистентной микрофлоры к тетрациклиновому ряду 11 больным назначался цефтриаксон внутримышечно в дозе 1,0-2,0 в сутки на протяжении 5-6 дней. Больные второй группы использовали антибактериальную терапию и терапию с включением препаратов нитроимидазольного ряда (метронидазол). Наружно пациенты обеих групп получали антибактериальные мази и специальную гамму «Розельян» дерматологической лаборатории «Урьяж», Франция. Мужчин было 31, женщин - 46. Возраст от 26 до 67 лет. Давность заболевания составила от 2-3 до 10 и более лет. Оценка тяжести течения розацеа проводилась согласно стандартным клиническим фрормам с применением шкалы диагностической оценки розацеа (ШДОР) и стандартной четырехбалльной шкалы (от нуля до трех баллов) [38].

Эритематозно-телеангиэктатическая фрорма розацеа наблюдалась у 36 человек (рис. 1a, 2a), папулопустулезная - у 35, у двоих диагностирован синдром Морбигана. Четверо пациентов-мужчин страдали ринофимой.

Больные обследованы на наличие гастродуоденальной патологии. Проводились ультразвуковая эхография гепатобилиарной системы, исследование биохимических параметров: уровень концентрации в периферической крови аминотрансфераз (АЛТ, ACT), гаммаглумилтранспептидазы (ГГТ), щелочной фосфратазы (ЩФ), липидных фракций - общий холестерин, триглицериды, липопротеиды высокой и низкой плотности, сахар крови, общий белок с альбумином и тимоловая проба. Биохимические параметры 15 здоровых добровольцев послужили группой контроля (табл. 5).

Статистическая обработка данных проводилась при помощи компьютерной программы STATISTICA for Windows. Для установления достоверности различий между группами использовался критерий Стьюдента. При сравнении вариационных рядов учитывались достоверные различия $(p<0,05)$.

\section{Результаты и обсуждение}

Среди сопутствующих заболеваний были отмечены хронический гастрит у 21 (27,3\%) больного, хронический гепатит у 33 (42,9\%) больных, явления жирового гепатоза печени констатированы у 37 (48,1\%) пациентов, наличие хронического пиелонефрита - у 11 $(14,3 \%)$ больных.

При оценке тяжести течения патологического кожного процесса по шкале ШДОР отмечено преобладание количества больных, страдавших умеренной степенью тяжести течения розацеа 43 (55,8\%). Легкая степень зарегистрирована у $23(29,9 \%)$ человек, и тяжелое течение наблюдалось у 11 (14,3\%) больных. У 36 больных эритематозно-телеангиэктатической формой розацеа средний балл составил 7,0 $\pm 0,13$, у 35 больных папуло-пустулезной формой - 10,17 \pm 0,32 и у четырех больных фриматозной клинической фрормой розацеа индекс тяжести составил 18,5 \pm 0,84 (табл. 6). Двое больных с синдромом Морбигана не включены в выборку.

Дополнительную информацию о состоянии гепатобилиарной и панкреатодуоденальной систем мы получили при ультразвуковой эхографии органов брюшной полости, позволившей выявить у большинства пациентов с розацеа наличие функциональной и органической патологии со стороны вышеуказанных органов, что нашло свое отражение в табл. 1.

Биохимическое исследование периферической крови позволило выявить следующие изменения: повышение активности АСТ у больных розацеа было достоверно отличным по сравнению с показателями здоровых лиц $\left(p_{1}<0,001\right)$ (табл. 2). Уровни содержания ГГТ и ЩФ также были повышены по сравнению с аналогичными данными здорового контроля $\left(p_{1}<0,001\right.$ и $\left.p_{1}<0,001\right)$. Высокий уровень ГГТ и ЩФ указывал на явления внутрипеченочного холестаза, который подтвержден данными ультразвуковой эхографии печени. Липидный спектр сыворотки крови 


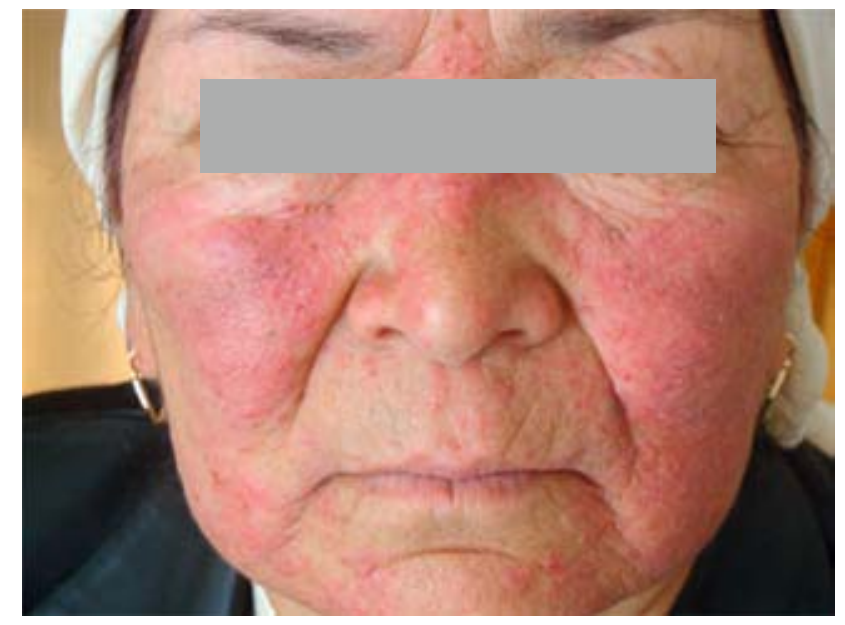

a

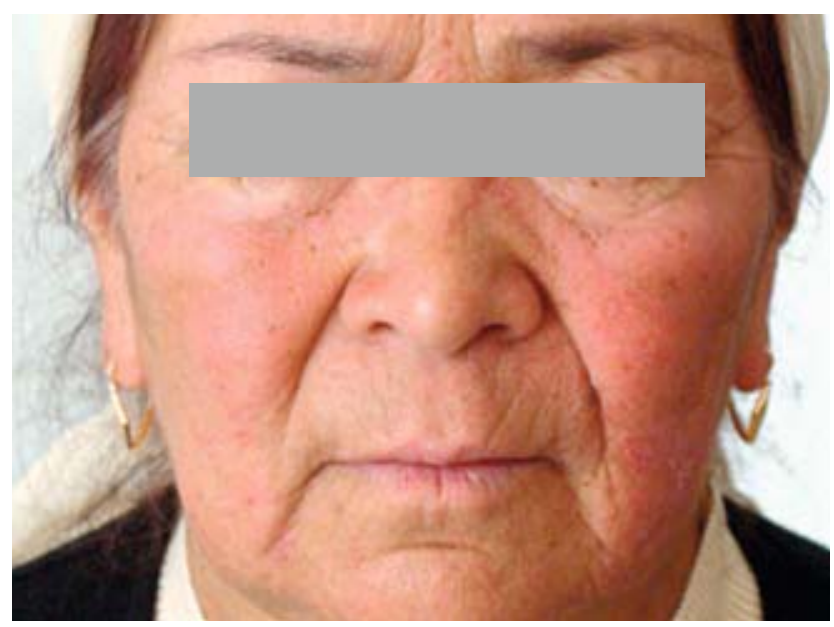

$\sigma$

Рис. 1. Больная П. 54 лет. Эритематозно-папулезная фрорма розацеа до лечения (а); после первого курса лечения (б)

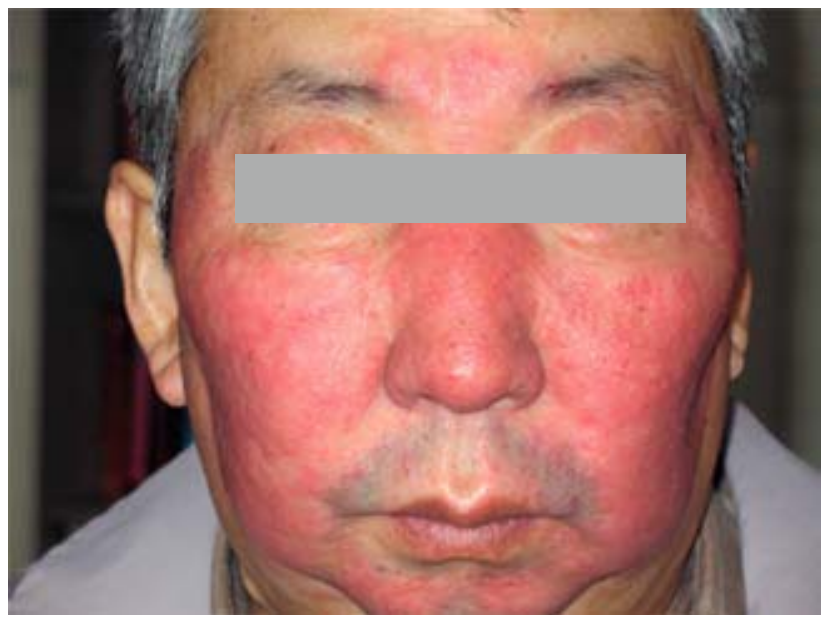

a

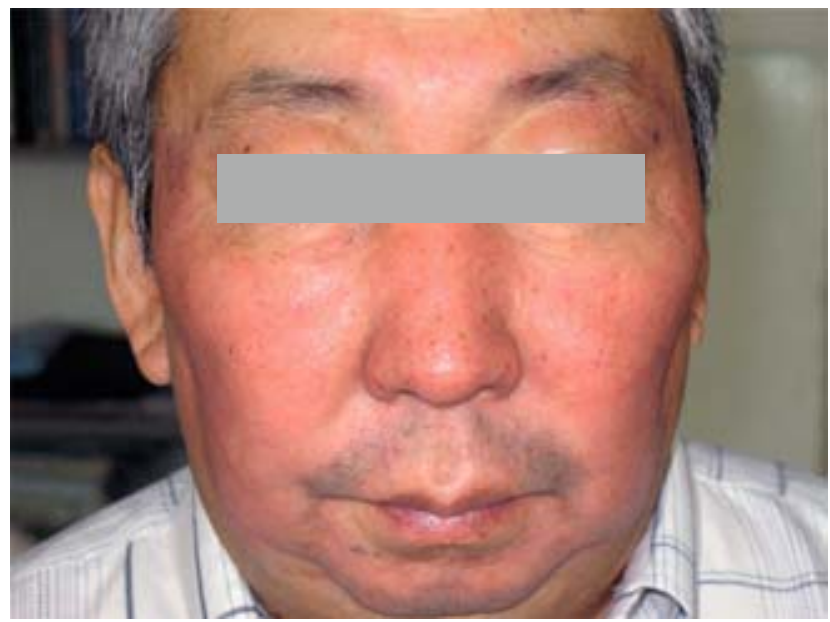

$\sigma$

Рис. 2. Больной А. 53 лет. Эритематозная стадия акне розацеа до лечения (a); после первого курса лечения (б)

больных до лечения был недостоверно значимым по сравнению с данными здоровых лиц.

Комплексная терапия L-аргинином и урсодезоксихолевой кислотой была эффективной у всех пролеченных больных розацеа. Больным в начале терапии назначался курс антибиотикотерапии с учетом выделенной микрофлоры, преимущественно препараты тетрациклинового ряда. Совместно применялся метронидазол 0,75-1,0 г в сутки на протяжении
10-15 дней одного курса лечения. L-аргинин назначался перорально по 500 мг 2 раза в сутки на протяжении 10 дней. При тяжелых формах препарат вводился парентерально с дальнейшим переходом на пероральную фрорму. Начиная с первого дня лечения больным назначалась урсодезоксихолевая кислота из расчета 10-15 мг на 1 кг массы больного в сутки на протяжении 15 дней. Препараты переносились хорошо, без побочных явлений. Только у двух паци- 
Таблица 1 Выявенные признаки фонкциональной и органической патологии при ультразвуковой диагностике органов брюшной полости у обследованных больных розацеа $(n=77)$

\begin{tabular}{lcc}
\hline Сонограсрический признак & \multicolumn{2}{c}{ Количество больных } \\
\hline Утолщение стенок желчного пузыря и десормация формы желчного пузыря & 57 & $74,03 \%$ \\
\hline Перекрут и изгиб шейки желчного пузыря & 16 & $20,8 \%$ \\
\hline Увеличение размеров печени & 25 & $32,5 \%$ \\
\hline Неоднородность структуры паренхимы печени & 42 & $54,5 \%$ \\
\hline Расширение внутрипеченочных желчных протоков & 31 & $40,3 \%$ \\
\hline Увеличение размеров желчного пузыря & 15 & $19,5 \%$ \\
\hline Неоднородность структуры изображения поджелудочной железы & $24,7 \%$ \\
\hline Изменения со стороны чашечно-лоханочной системы почек & 19 & $14,3 \%$ \\
\hline
\end{tabular}

Таблица 2 Биохимические показатели у больных розацеа до патогенетического лечения $(n=77)$

\begin{tabular}{|c|c|c|c|c|c|c|c|c|c|c|c|c|}
\hline $\begin{array}{l}\text { Общий } \\
\text { били- } \\
\text { рубин }\end{array}$ & АЛТ & ACT & ГГТ & ЩФ & $\begin{array}{l}\text { Сахар } \\
\text { крови }\end{array}$ & $\begin{array}{l}\text { Общий } \\
\text { белок }\end{array}$ & $\begin{array}{c}\text { Холес- } \\
\text { терин }\end{array}$ & ЛПВП & ЛПНП & $\mathrm{T} \Gamma$ & $\begin{array}{c}\text { Альбу- } \\
\text { мин }\end{array}$ & $\begin{array}{c}\text { Тимоло- } \\
\text { вая } \\
\text { проба }\end{array}$ \\
\hline $\begin{array}{l}15,66 \pm \\
1,36\end{array}$ & $\begin{array}{c}26,68 \pm \\
1,37\end{array}$ & $\begin{array}{c}23,77 \pm \\
1,78\end{array}$ & $\begin{array}{c}32,91 \pm \\
2,45\end{array}$ & $\begin{array}{c}137,45 \pm \\
1,88\end{array}$ & $\begin{array}{c}4,74 \pm \\
0,12\end{array}$ & $\begin{array}{c}72,31 \pm \\
2,27\end{array}$ & $\begin{array}{c}4,56 \pm \\
0,15\end{array}$ & $\begin{array}{c}1,35 \pm \\
0,08\end{array}$ & $\begin{array}{c}2,66 \pm \\
0,23\end{array}$ & $\begin{array}{c}1,45 \pm \\
0,22\end{array}$ & $\begin{array}{c}45,63 \pm \\
2,12\end{array}$ & $\begin{array}{c}3,74 \pm \\
0,37\end{array}$ \\
\hline $\begin{array}{l}p<0,02 \\
p_{1}<0,001\end{array}$ & $\begin{array}{c}p<0,001 \\
p_{1}>0,1\end{array}$ & $\begin{array}{l}p<0,001 \\
p_{1}<0,001\end{array}$ & $\begin{array}{l}p<0,001 \\
p_{1}<0,001\end{array}$ & $\begin{array}{l}p<0,001 \\
p_{1}<0,001\end{array}$ & $\begin{array}{l}p>0,1 \\
p_{1}>0,1\end{array}$ & $\begin{array}{l}p>0,1 \\
p_{1}>0,1\end{array}$ & $\begin{array}{c}p>0,1 \\
p_{1}<0,01\end{array}$ & $\begin{array}{l}p>0,1 \\
p_{1}>0,1\end{array}$ & $\begin{array}{l}p>0,1 \\
p_{1}>0,1\end{array}$ & $\begin{array}{l}p>0,1 \\
p_{1}<0,1\end{array}$ & $\begin{array}{l}p>0,1 \\
p_{1}>0,1\end{array}$ & $\begin{array}{c}p<0,05 \\
p_{1}<0,001\end{array}$ \\
\hline
\end{tabular}

Примечание. Здесь и в табл. 3-5: $p$ - статистические различия показателей до лечения с аналогичными данными после лечения; $p_{1}-$ статистические различия показателей до лечения с аналогичными данными здоровых лиц; $p_{2}-$ статистические различия показателей после лечения с аналогичными данными здоровых лиц.

Таблица 3 Биохимические показатели у больных основной группы розацеа после лечения $(n=45)$

\begin{tabular}{|c|c|c|c|c|c|c|c|c|c|c|c|c|}
\hline $\begin{array}{l}\text { Общий } \\
\text { били- } \\
\text { рубин }\end{array}$ & АЛТ & ACT & ГГТ & ЩФ & $\begin{array}{l}\text { Сахар } \\
\text { крови }\end{array}$ & $\begin{array}{l}\text { Общий } \\
\text { белок }\end{array}$ & $\begin{array}{c}\text { Холес- } \\
\text { терин }\end{array}$ & ЛПВП & ЛПНП & ТГ & $\begin{array}{c}\text { Альбу- } \\
\text { мин }\end{array}$ & $\begin{array}{c}\text { Тимоло- } \\
\text { вая } \\
\text { проба }\end{array}$ \\
\hline $\begin{array}{l}10,64 \pm \\
1,25\end{array}$ & $\begin{array}{c}12,53 \pm \\
1,67\end{array}$ & $\begin{array}{c}13,50 \pm \\
0,43\end{array}$ & $\begin{array}{c}21,42 \pm \\
0,72\end{array}$ & $\begin{array}{c}72,31 \pm \\
1,21\end{array}$ & $\begin{array}{c}4,25 \pm \\
0,34\end{array}$ & $\begin{array}{c}74,56 \pm \\
0,28\end{array}$ & $\begin{array}{c}4,47 \pm \\
0,37\end{array}$ & $\begin{array}{c}1,29 \pm \\
0,42\end{array}$ & $\begin{array}{c}2,46 \pm \\
0,22\end{array}$ & $\begin{array}{c}1,15 \pm \\
0,36\end{array}$ & $\begin{array}{c}44,3 \pm \\
1,43\end{array}$ & $\begin{array}{c}2,89 \pm \\
0,78\end{array}$ \\
\hline$p_{2}>0,05$ & $p_{2}>0,05$ & $p_{2}>0,05$ & $p_{2}>0,05$ & $p_{2}<0,001$ & $p_{2}>0,1$ & $p_{2}>0,1$ & $p_{2}>0,1$ & $p_{2}>0,1$ & $p_{2}>0,1$ & $p_{2}>0,1$ & $p_{2}>0,1$ & $p_{2}>0,1$ \\
\hline
\end{tabular}

Таблица 4 Биохимические показатели у больных группы сравнения розацеа после лечения $(n=19)$

\begin{tabular}{|c|c|c|c|c|c|c|c|c|c|c|c|c|}
\hline $\begin{array}{l}\text { Общий } \\
\text { били- } \\
\text { рубин }\end{array}$ & АЛТ & ACT & ГГТ & ЩФ & $\begin{array}{l}\text { Сахар } \\
\text { крови }\end{array}$ & $\begin{array}{l}\text { Общий } \\
\text { белок }\end{array}$ & $\begin{array}{l}\text { Холес- } \\
\text { терин }\end{array}$ & ЛПВП & ЛПНП & ТГ & $\begin{array}{c}\text { Альбу- } \\
\text { мин }\end{array}$ & $\begin{array}{c}\text { Тимоло- } \\
\text { вая } \\
\text { проба }\end{array}$ \\
\hline $\begin{array}{l}13,42 \pm \\
1,48\end{array}$ & $\begin{array}{c}17,58 \pm \\
1,34\end{array}$ & $\begin{array}{c}16,31 \pm \\
0,44\end{array}$ & $\begin{array}{c}28,46 \pm \\
1,23\end{array}$ & $\begin{array}{c}89,55 \pm \\
1,32\end{array}$ & $\begin{array}{c}4,54 \pm \\
0,17\end{array}$ & $\begin{array}{c}78,33 \pm \\
1,47\end{array}$ & $\begin{array}{c}4,18 \pm \\
0,17\end{array}$ & $\begin{array}{c}1,39 \pm \\
0,42\end{array}$ & $\begin{array}{c}2,43 \pm \\
0,12\end{array}$ & $\begin{array}{c}1,21 \pm \\
0,54\end{array}$ & $\begin{array}{c}45,9 \pm \\
1,41\end{array}$ & $\begin{array}{c}2,35 \pm \\
0,47\end{array}$ \\
\hline $\begin{array}{l}p>0,1 \\
p_{2}<0,01\end{array}$ & $\begin{array}{c}p<0,001 \\
p_{2}>0,1\end{array}$ & $\begin{array}{l}p<0,001 \\
p_{2}<0,001\end{array}$ & $\begin{array}{c}p>0,1 \\
p_{2}<0,01\end{array}$ & $\begin{array}{l}p<0,001 \\
p_{2}<0,001\end{array}$ & $\begin{array}{l}p>0,1 \\
p_{2}>0,1\end{array}$ & $\begin{array}{l}p<0,05 \\
p_{2}<0,05\end{array}$ & $\begin{array}{l}p>0,1 \\
p_{2}>0,1\end{array}$ & $\begin{array}{l}p>0,1 \\
p_{2}>0,1\end{array}$ & $\begin{array}{l}p>0,1 \\
p_{2}>0,1\end{array}$ & $\begin{array}{l}p>0,1 \\
p_{2}>0,1\end{array}$ & $\begin{array}{l}p>0,1 \\
p_{2}>0,1\end{array}$ & $\begin{array}{l}p<0,05 \\
p_{2}>0,05\end{array}$ \\
\hline
\end{tabular}


Таблица 5 Биохимические параметры здоровых лиц $(n=15)$

\begin{tabular}{|c|c|c|c|c|c|c|c|c|c|c|c|c|}
\hline $\begin{array}{l}\text { Общий } \\
\text { били- } \\
\text { рубин }\end{array}$ & АЛТ & ACT & ГГТ & ЩФ & $\begin{array}{l}\text { Сахар } \\
\text { крови }\end{array}$ & $\begin{array}{l}\text { Общий } \\
\text { белок }\end{array}$ & $\begin{array}{l}\text { Холес- } \\
\text { терин }\end{array}$ & ЛПВП & ЛПНП & ТГ & $\begin{array}{c}\text { Альбу- } \\
\text { мин }\end{array}$ & $\begin{array}{c}\text { Тимоло- } \\
\text { вая } \\
\text { проба }\end{array}$ \\
\hline $8,2 \pm 0,6$ & $\begin{array}{c}17,3 \pm \\
1,9\end{array}$ & $\begin{array}{c}11,8 \pm \\
1,1\end{array}$ & $\begin{array}{c}21,65 \pm \\
1,72\end{array}$ & $\begin{array}{c}55,75 \pm \\
2,19\end{array}$ & $\begin{array}{c}4,37 \pm \\
0,14\end{array}$ & $\begin{array}{c}74,0 \pm \\
0,98\end{array}$ & $\begin{array}{c}3,81 \pm \\
0,2\end{array}$ & $\begin{array}{l}1,14 \pm \\
0,073\end{array}$ & $\begin{array}{c}2,16 \pm \\
0,16\end{array}$ & $\begin{array}{c}1,02 \pm \\
0,09\end{array}$ & $\begin{array}{c}43,4 \pm \\
1,1\end{array}$ & $\begin{array}{c}1,6 \pm \\
0,2\end{array}$ \\
\hline
\end{tabular}

$\begin{array}{ll}\text { Таблица } 6 & \text { Балльная оценка индекса тяжести различных клинических форм у больных розацеа до лечения } \\ (n=75)\end{array}$

\begin{tabular}{lcc}
\hline Клиническая фрорма & Количество больных & Количество баллов \\
\hline Эритематозно-телеангиэктатическая & 36 & $7,0 \pm 0,13$ \\
& & $p<0,001$ \\
\hline Папуло-пустулезная & 35 & $10,17 \pm 0,32$ \\
& & $p<0,001$ \\
\hline Фиматозная & 4 & $18,5 \pm 0,84$ \\
& & $p<0,02$ \\
\hline
\end{tabular}

Примечание. Здесь и в табл. 7, 8: $p$ - статистические различия показателей больных до лечения с аналогичными данными больных основной группы после лечения; $p_{1}$ — статистические различия показателей больных основной группы после лечения с данными группы сравнения после лечения; $p_{2}-$ статистические различия показателей больных до лечения с аналогичными данными группы сравнения после лечения.

Таблица 7 Балльная оценка эфффективности терапии розацеа основной группы больных после лечения $(n=45)$

\begin{tabular}{lcc}
\hline Клиническая форма & Количество больных & Количество баллов \\
\hline Эритематозно-телеангиэктатическая & 21 & $2,48 \pm 0,18$ \\
& & $p_{1}<0,001$ \\
\hline Папуло-пустулезная & 20 & $3,2 \pm 0,41$ \\
& & $p_{1}<0,001$ \\
\hline Фиматозная & 4 & $12,25 \pm 1,12$ \\
& & $p<0,02$ \\
\hline
\end{tabular}

Таблица 8 Балльная оценка эфрфективности терапии больных розацеа группы сравнения $(n=24)$

\begin{tabular}{lcc}
\hline Клиническая фрорма & Количество больных & Количество баллов \\
\hline Эритематозно-телеангиэктатическая & 14 & $4,56 \pm 0,36$ \\
& & $p_{2}<0,001$ \\
\hline Папуло-пустулезная & 10 & $6,4 \pm 0,43$ \\
& & $p_{2}<0,001$ \\
\hline
\end{tabular}

ентов наблюдалось учащение дефекации за счет холеретического эфффекта урсодезоксихолевой кислоты. Курс лечения в среднем состоял из 15-25 дней. Значительное клиническое улучшение после первого курса лечения наблюдалось у 36 (70,5\%) больных, улучшение - у $12(23,5 \%)$ и без изменений - у троих $(5,9 \%)$ пациентов (рис. 16,26$)$.
Оценка терапевтической эффрективности по шкале ШДОР показала достоверное уменьшение баллов после трехмесячного патогенетического лечения (табл. 7).

У 24 больных группы сравнения значительное клиническое улучшение отмечено у 11 (45,8\%), улучшение - у 5 (20,8\%) и без изменений - у 8 (33,3\%) пациентов. Оценка терапевтической эфффективности 
по шкале ШДОР также показала достоверное уменьшение баллов по сравнению с данными до лечения (табл. 8). При сравнении полученных результатов лечения в основной группе и в группе сравнения у больных розацеа показатели были достоверно различны $p_{2}$.

Проведение комплексной патогенетической терапии у больных с различными клиническими формами розацеа с применением L-аргинина и урсодезоксихолевой кислоты способствовало уменьшению воспалительных изменений в области лица, которое проявлялось рассасыванием папул, исчезновением пустулезных элементов и уменьшением воспалительной инфильтрации. Отмечено исчезновение зуда и боли в очагах поражений. Улучшение кожного процесса у больных основной группы розацеа сопровождалось уменьшением гиперемии и отека тканей лица. Клиническое наблюдение показало, что регресс высыпаний составил примерно 15-20 дней (в среднем 17,4 \pm 0,67 дня) с момента начала терапии. Повторный курс лечения назначался спустя 20-25 дней после проведения первого. В среднем для полного клинического выздоровления больных требовалось 2-3 курса патогенетической терапии с интервалами 1,5-2 месяца.

После проведенного курса лечения биохимические параметры исследованы у 45 больных розацеа, получавших основной курс лечения (табл. 3). Положительная динамика кожного процесса коррелировала с показателями лабораторных данных у наблюдаемых больных и сопровождалась снижением уровня аминотрансфераз, ГГТ и ЩФ печени до референсных значений. У 19 больных группы сравнения, получавших традиционную патогенетическую терапию, но без включения аргинина и урсодезоксихолевой кислоты, биохимические показатели в основном статистически разнились с данными группы до лечения по аминотрансферазам, щелочной фосфратазе, общему белку и тимоловой пробе (табл. 4).

Использование предлагаемого способа позволило получить клиническое излечение у 73\% больных, значительное улучшение в 27\% случаев после трех курсов профрилактического лечения. Повторные курсы с целью закрепления терапевтического эффекта лечения у больных розацеа пероральной формой L-аргинина и препаратом урсодезоксихолевой кислоты проводились по 10-15 дней, не более трех с интервалами в один месяц. Срок давности наблюдений 1,5-2 года. При этом рецидивы заболевания наблюдались у 21 (27,3\%) больного, которым повторно назначалась вышеуказанная терапия пероральным L-аргинином и урсодезоксихолевой кислотой с положительной клинической динамикой.

Таким образом, полученные данные свидетельствуют о фрункциональном участии гепатобилиарной системы в развитии системного патологического процесса у больных розацеа. Подтверждением этому служит положительный клинический эффрект применения L-аргинина и урсодезоксихолевой кислоты, полученный у больных розацеа.

L-аргинин индуцирует в печени синтез $\mathrm{NO}^{-}$, который влияет на функции гепатоцитов, повышает устойчивость этих клеток к оксидативному стрессу, препятствует ишемическим процессам в тканях, способствует улучшению репаративных свойств клеток. Наилучшим образом цитопротекторное действие $\mathrm{NO}^{-}$обусловлено его способностью предотвращать агрегацию и адгезию тромбоцитов, а также нейтрализацией токсичных радикалов кислорода [40].

$\mathrm{NO}^{-}$участвует в регуляции тонуса церебральных сосудов, тем самым способствует улучшению мозгового кровотока $[41,43]$. Снижение $\mathrm{NO}^{-}$в эндотелии сосудов является одним из предикторов развития артериальной гипертензии, способствует развитию атеросклероза, нарушению липидного состава крови больных [42]. В связи с этим патогенетически обоснованным выглядит применение L-аргинина в терапии розацеа как одного из факторов уменьшения застойных явлений в центральной части лица. Использование L-аргинина улучшает когнитивные способности человека, он обладает нейромодулирующей способностью [42].

Вышеуказанный способ не требовал высоких материальных затрат, был прост при воспроизведении, высокоэффективен, не имел побочных явлений, характерных для других методов лечения розацеа.

\section{Выводы}

1. L-аргинин и урсодезоксихолевая кислота являются эффрективными препаратами в комплексной терапии розацеа, особенно в терапии тяжелых клинических форм. Препараты показаны в качестве дополнительного метода лечения, не обладающего побочными явлениями.

2. Оптимальной дозой L-аргинина является 500 мг дважды в сутки, урсодезоксихолевой кислоты 10-15 мг/кг массы больного в сутки.

3. Для достижения значительного клинического эффректа в терапии розацеа требуется в среднем 2-3 курса патогенетической терапии L-аргинином и урсодезоксихолевой кислотой в комплексе с другими лекарственными средствами.

4. Терапия L-аргинином и урсодезоксихолевой кислотой может применяться также при тяжелых проявлениях розацеа, не требуя существенных материальных затрат, и может проводиться как в стационарных, так и в амбулаторных условиях. I 


\section{Литература}

1. Starchenko M.E. Demenkova N.V., Danilova E.N. 0 differentsialnoy diagnostike rozovyih ugrey. Vestn dermatol venerol 1998; 5 : 57-58. [Старченко М.Е. Деменкова Н.В., Данилова Е.Н. 0 дифференциальной диагностике розовых угрей. Вестн дерматол венерол 1998; 5: 57—58.]

2. Berg M., Liden S. An epidemiological study of rosacea. Acta dermatol.(Stockh.) 1989; 69: 5: 419-423.

3. Schaefer I., Rustenbach S.J., Zimmer L., Augustin M. Prevalence of skin diseases in a cohort of 48,665 employees in Germany. Dermatology (Basel) 2008; 217: 169—72. doi: 10.1159/000136656

4. Abram K., Silm H., Oona M. Prevalence of rosacea in an Estonian working population using a standard classification. Acta Derm Venereol 2010; 90: 269 —73. doi: 10.2340/00015555-0856.

5. Wilkin J., Dahl M., Detmar M. et al. Standard classification of rosacea: Report of the National Rosacea Society Expert Committee on the classification and staging of rosacea. J Am Acad Dermatol 2002; 46 (4): 584—587.

6. Khaled A., Hammami H., Zeglaoui F., Tounsi J., Zermani R., Kamoun M.R., Fazaa B. Rosacea: 244 Tunisian cases. Tunis Med 2010; 88: 597—601.

7. Koczulla R., Degenfeld G. von, Kupatt C., Krötz F., Zahler S., Gloe T., Issbrücker K., Unterberger P., Zaiou M., Lebherz C., Karl A., Raake P., Pfosser A., Boekstegers P., Welsch U., Hiemstra P.S., Vogelmeier C., Gallo R.L., Clauss M., Bals R. An angiogenic role for the human peptide antibiotic LL-37/hCAP-18. J Clin Invest.2003; 111: 1665-72. doi: 10.1172/JCI17545.

8. Dorschner R.A., Pestonjamasp V.K., Tamakuwala S., Ohtake T., Rudisill J., Nizet V., Agerberth B., Gudmundsson G.H., Gallo R.L. Cutaneous injury induces the release of cathelicidin anti-microbial peptides active against group A Streptococcus. J Invest Dermatol 2001; 117: 91-7. doi: 10.1046/.1523-1747.2001.01340.x.

9. Holmes A.D. Potential role of microorganisms in the pathogenesis of rosacea. J Am Acad Dermatol 2013; 69 (6): 1025-1032.

10. Georgala S., Katoulis A.C., Kylafis G.D., Koumantaki-Mathioudaki E., Georgala C., Aroni J. Increased density of Demodex folliculorum and evidence of delayed hypersensistivity reaction in subjects with papulopustular rosacea. J Eur Acad Dermatol Venereol 2001; 15 (5): 441—444.

11. Yamasaki K., Kanada K., Macleod D.T., Borkowski A.W., Morizane S., Nakatsuji T., Cogen A.L., Gallo R.L. TLR2 expression is increased in rosacea and stimulates enhanced serine protease production by keratinocytes. J Invest Dermatol 2011; 131: 688-97. doi: 10.1038/jid. 2010. 351.

12. Kim J.T., Lee S.H., Chun Y.S. et al. Tear cytokines and chemokines in patients with Demodex blepharitis. Cytokine 2011; 53: 94—9.
13. Aubdool A.A., Brain S.D. Neurovascular aspects of skin neurogenic inflammation. J Investig Dermatol Symp Proc 2011; 15: 33-9.

14. Sulk M., Seeliger S., Aubert J., Schwab V.D., Cevikbas F., Rivier M., Nowak P., Voegel J.J., Buddenkotte J., Steinhoff M. Distribution and expression of non-neuronal transient receptor potential (TRPV) ion channels in rosacea. J Invest Dermatol 2012; 132: 1253—62.

15. Wittkower E., Russell B. Emotional factors in skin disease. New York: Hoeber 1953; 359_362.

16. Usher B. Gastroscopic observation in rosacea. Arch. Dermatol. Syphil 1941; 44: 251—255.

17. Gluhenkiy B.T., Chopik E.A., Snitsarenko O.V. Funktsionalnoe sostoyanie pecheni u bolnyih rozatsea po dannyim radionuklidnyih issledovaniy. Vestn dermatol venerol 1986; 7: 38-40. [Глухенький Б.Т., Чопик Е.А., Сницаренко О.В. Функциональное состояние печени у больных розацеа по данным радионуклидных исследований. Вестн дерматол венерол 1986; 7: 38 — 40.]

18. Funk C.F. Rosacea und Leberfunctionsprufung. Eine neuralpathologische Studie zur polygenetischen Problematik der Rosacea. Arch. Dermatol. Syphil 1950; 191: 146-155.

19. Kobtseva O.V., Filippenko N.G., Pismennaya E.V., Pulikov A.E. Effektivnost primeneniya fosfogliva $\checkmark$ kompleksnoy terapii bolnyih rozatsea. Kurskiy nauchno-prakticheskiy vestnik «Chelovek i ego zdorov'e» 2011; 1: 41-44. [Кобцева 0.В., Филиппенко Н.Г., Письменная Е.В., Пуликов А.Е. Эфффективность применения фоссфоглива в комплексной терапии больных розацеа. Курский научно-практический вестник «Человек и его здоровье» 2011; $1: 41$-44.]

20. Kurdina M.I., Potekaev N.N., Potekaev S.N., Lvov A.N. Sovremennyie predstavleniya o patogeneze rozatsea. Vestn dermatol venerol 1998; 2: 16-21. [Курдина М.И., Потекаев Н.Н., Потекаев С.Н. Львов А.Н. Современные представления о патогенезе розацеа. Вестн дерматол венерол 1998; 2: 16—21.]

21. Lalaeva A.M., Danilov S.I., Piryatinskaya V.A., Gribanova T.V. Sovremennyie predstavleniya o patogeneze i lechenii rozatsea. Klin dermatol venerol 2003; 2: 29-34. [Лалаева А.М., Данилов С.И., Пирятинская В.А., Грибанова Т.В. Современные представления о патогенезе и лечении розацеа. Клин дерматол венерол 2003; 2: 29-34.]

22. Abragamovich L.E., Lavrik A.U. Sostoyanie gastroduodenalnoy i gepatobiliarnoy sistem u bolnyih rozatsea, allergo- i sistemnyimi dermatozami. L'vov 1990; 61—62. [Абрагамович Л.Е., Лаврик А.У. Состояние гастродуоденальной и гепатобилиарной систем у больных розацеа, аллерго- и системными дерматозами. Львов 1990; 61-62.]

23. Sigl I., Bauerdorf R. Granulematous rosacea associated with ulcerative colitis: 2 case reports. Z. Hautkr 1989; 64: 6: 499—502.
24. Parish L.C., Witkowski J.A. Acne rosacea and Helicobacter pylori betrothed. Int. J. Dermatol 1995; 34: 4: 237-238.

25. Polyah Ya.A. Rol patologii zheludochno-kishechnogo trakta v patogeneze rozatsea. Zhurnal dermatovenerologii i kosmetologii im. M.0. Torsueva 2011; 24: 1—2, 103-107. [Полях Я.А. Роль патологии желудочно-кишечного тракта в патогенезе розацеа. Журнал дерматовенерологии и косметологии им. М.О. Торсуева 2011; 24: 1-2, 103-107].

26. Fry L., Swann J.S. Gastrocamera studies in rosacea. Br. J. Dermatol 1968; 80: 737-739.

27. Rebora A., Drago F., Picciotto A. Helicobacter pylori in patients with rosacea. Am. J. Gastroenterol 1994; 89: 1603-1604.

28. Del Rosso J.Q., Thiboutot D., Gallo R. et al. Consensus recommendations from the American Acne and Rosacea Society on the management of rosacea. Part 3: a status report on systemic therapies. Cutis 2014; 93 (1): 18-28.

29. Daly J.M., Lieberman M.D., Goldfine J. et. al. Enleral nutrition with upplemental arginine, RNA, and omega-3 fatty acids in patients after operation: immunologic, metabolic and clinical outcome // Surgery 1992; 112: 56—67.

30. Darmaun D., Matthews D.E, Bier D.M. Glutamine and glutamate kinetics in humans // Am. J. Physiol 1986; 251: 117-126.

31. Vanin A.F. Oksid azota v biologii: istoriya, sostoyanie i perspektivyi issledovaniy // Biohimiya 1998; 7: 867-869. [Ванин А. Ф. Оксид азота в биологии: история, состояние и перспективы исследований // Биохимия 1998; 7: 867-869.]

32. Vanin A.F. Oksid azota v biomeditsinskih issledovaniyah // Vestn. RAMN 2000; 4: 3-5. [Ванин А.Ф. Оксид азота в биомедицинских исследованиях // Вестн. РАМН 2000; 4: 3-5.]

33. Cynober $L$. Can arginine and ornithine support gut functions? // Gut. 1994; 35 Suppl. P. S. 42—S45.

34. Gozhenko A.I., Nikolaevskaya I.V., Kotyuzhinskaya S.T., Babiy V.P. Oksid azota i immunnaya sistema organizma // Med. himiya. 2001; 3: 5-9. ГГоженко А.И., Николаевская И.В., Котюжинская С.Т., Бабий В.П. Оксид азота и иммунная система организма // Мед. хімія. 2001; 3: 5-9.]

35. Bueverov A.0. Mesto ursodezoksiholevoy kislotyi v lechenii alkogolnoy bolezni pecheni. Klinicheskie perspektivyi gastroenterologii, gepatologii 2004; 1: 15-20. [Буеверов А.0. Место урсодезоксихолевой кислоты в лечении алкогольной болезни печени. Клинические перспективы гастроэнтерологии, гепатологии 2004; 1: 15-20.]

36. Nadinskaya M.Yu. Issledovanie primeneniya ursodezoksiholevoy kislotyi v gepatologii s pozitsii meditsinyi, osnovannoy na nauchnyih dokazatelstvah. Consilium medicum 2003; 6: 318-322. [Надинская М.Ю. Исследование применения урсодезоксихолевой кислоты в гепатологии 
с позиции медицины, основанной на научных доказательствах. Consilium medicum 2003; 6 : 318-322.]

37. Baltabaev M.K., Sadyikova D.A., Koybagarova A.A. Opyit primeneniya ursodezoksiholevoy kislotyi $v$ kompleksnoy terapii bolnyih atopicheskim dermatitom. Vestn dermatol venerol 2011; 3: 56-63. [Балтабаев М.К., Садыкова Д.А., Койбагарова А.А. Опыт применения урсодезоксихолевой кислоты в комплексной терапии больных атопическим дерматитом. Вестн дерматол венерол 2011; 3: 56 —63.]

38. Adaskevich V.P. Diagnosticheskie indeksyi $\checkmark$ dermatologii. M.: Izdatelstvo Panfilova; BlNOM. Laboratoriya znaniy 2014; 352. [Адаскевич В.П. Диагностические индексы в дерматологии. М.: Изд-во Пансфилова; БИНОМ. Лаборатория знаний 2014; 352.$]$
39. Baltabaev M.K., Shakirova A.T. Sposob lecheniya rozovyih ugrey. Patent na izobretenie N 1759 ot 31. 07. 2015 goda Intellektualdyik menchik (Intellektualnaya sobstvennost). Ofitsialnyiy byulleten, Bishkek, 2015, 7. [Балтабаев М.К., Шакирова А.Т. Способ лечения розовых угрей. Патент на изобретение № 1759 от 31.07.2015 г. Интеллектуалдык менчик (Интеллектуальная собственность). Офицциальный бюллетень. Бишкек, 2015, № 7.]

40. Malyishev I.Yu., Manuhina E.B. Stress, adaptatsiya i oksid azota. Biohimiya 1998; 7 : 992-1006. [Малышев И. Ю., Манухина Е. Б. Стресс, адаптация и оксид азота. Биохимия 1998; 7: 992—1006.]

41. Belousov Yu.B., Namsaraev Zh.N. Endotelialnaya disfunktsiya kak prichina ateroskleroticheskogo porazheniya arteriy pri arterialnoy gipertenzii: metodyi korrektsii. Farmateka, 2004; 6 (84): 62-72. [Белоусов Ю.Б., Намсараев Ж.Н. Эндотелиальная диссфункция как причина атеросклеротического поражения артерий при артериальной гипертензии: методы коррекции. Фарматека, 2004; 6 (84): 62-72.]

42. Gornik H.L., Creager M.A. Arginine and endothelial and vascular health. J. Nutr., 2004; 134 : 2880-2887.

43. Malahov V.A., Zavgorodnyaya A.N. Sistema oksida azota pri tserebralnom ishemicheskom insulte: nekotoryie patogeneticheskie aspektyi. Ukr. med. chasopis 2007; 2 (58): 97-100. [Малахов В.А., Завгородняя А.Н. Система оксида азота при церебральном ишемическом инсульте: некоторые патогенетические аспекты. Укр. мед. часопис 2007; 2 (58): 97-100.]

об авторах:

М.К. Балтабаев - д.м.н., профессор кафедры дерматовенерологии и фтизиатрии Кыргызско-Российского Славянского университета им. первого президента России Б.Н. Ельцина, Бишкек, Кыргызская Республика

А.Т. Шакирова - ассистент каффедры дерматовенерологии Кыргызской государственной медицинской академии им. И.К. Ахунбаева, Бишкек, Кыргызская Республика

А.М. Балтабаев - преподаватель кафредры дерматовенерологии и фртизиатрии Кыргызско-Российского Славянского университета им. первого президента России Б.Н. Ельцина, Бишкек, Кыргызская Республика

\section{Конфликт интересов}

Авторы заявляют об отсутствии потенциального конорликта интересов, требующего раскрытия в данной статье 